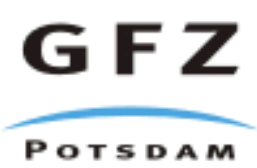

Originally published as:

Moreno, M., Klotz, J., Melnick, D., Echtler, H. P., Bataille, K. (2008): Active faulting and heterogeneous deformation across a megathrust segment boundary from GPS data, southcentral Chile (36-39\{degree sign\}S). - Geochemistry, Geophysics, Geosystems, 9, Q12024

DOI: 10.1029/2008GC002198. 


\section{Active faulting and heterogeneous deformation across a megathrust segment boundary from GPS data, south-central Chile $\left(36-39^{\circ} \mathrm{S}\right)$}

M. S. Moreno, ${ }^{1}$ J. Klotz, ${ }^{1}$ D. Melnick, ${ }^{2}$ H. Echtler, ${ }^{1,2}$ and K. Bataille ${ }^{3}$

M. S. Moreno, Department of Geodesy and Remote Sensing, Helmholtz Centre Potsdam, Telegrafenberg, 14473 Potsdam, Germany. (marcos@gfz-potsdam.de)

${ }^{1}$ Helmholtz-Zentrum Potsdam, Germany.

${ }^{2}$ Institut für Geowissenschaften,

Universität Potsdam, Germany.

${ }^{3}$ Departamento de Ciencias de la Tierra,

Universidad de Concepción, Chile. 


\section{Abstract.}

This study focuses on the present-day deformation mechanisms of the southcentral Chile margin, at the transition zone between two megathrust-earthquake segments defined from historical data: the Valdivia and Concepción sectors. New GPS data and finite-element models with complex geometries constrained by geophysical data are presented to gain insight into forearc kinematics and to address the role of upper-plate faults on contemporary deformation. GPS vectors are heterogeneously distributed in two domains that follow these two earthquake segments. We find that models which simulate only interseismic locking on the plate interface fail to reproduce surface deformation in the entire study area. In the Concepción domain, models that include a crustalscale fault in the upper plate better reproduce the GPS observations. In the Valdivia domain, GPS data show regional-scale vertical-axis rotations, which could reflect postseismic deformation processes at the edge of the $M_{w} 9.5$ earthquake that ruptured in 1960 and/or activity of another crustal fault related to motion of a forearc sliver. Our study suggests that upper-plate faults in addition to earthquake-cycle transients may exert an important control on the surface velocity of subduction-zone forearcs. 


\section{Introduction}

Contemporary deformation along active subduction margins primarily responds to the phases of the earthquake cycle [e.g., Thatcher and Rundle, 1979; Thatcher, 1984]. This cycle is a transient and repetitive process conditioned by the mechanical coupling between the continental and oceanic plates. During the interseismic phase of the earthquake cycle, high coupling between both plates results in the accumulation of contractional strain across the continental plate, as shown by numerical and analytical models constrained by geodetic data [e.g., Savage et al., 1981; Hyndman and Wang, 1995; Mazzotti et al., 2000]. The distribution of interseismic contractional strain is thought to be generally ruled by the width of the interplate seismogenic zone and its degree of locking [e.g., Savage, 1983]. The strain accumulated during the interseismic phase is mostly elastic and almost completely recovered by earthquake-related fault motion during the coseismic phase of the cycle [e.g., Allmendinger et al., 2007]. Coseismic earthquake rupture may be followed by a transient phase of postseismic deformation when either aseismic fault slip [e.g., Tse and Rice, 1986; Hsu et al., 2006] and/or prolonged viscoelastic relaxation of the mantle may occur [e.g., Rundle, 1978].

Although most of the forearc deformation is controlled by the megathrust, faults in the upper plate may contribute in releasing the elastic strain accumulated by plate convergence, either during an earthquake as documented in Alaska [Plafker, 1972] and postulated in Japan [Park et al., 2002], New Zealand [Barnes et al., 2002] and Chile [Melnick et al., 2006a], or presumably during the interseismic phase [e.g., McCaffrey and Goldfinger, 1995; McCaffrey et al., 2007], or both. The effect of motion on these upper-plate faults is ex- 
pressed as short wavelength, but high-amplitude deformation localized in the vicinity of the structure. These faults may be crustal-scale features rooted in the subduction interface and long-lived, controlling the formation of forearc basins over millions of years [e.g., Barnes et al., 2002; Melnick et al., 2006a]. In some subduction zones where plate convergence is oblique to the margin, forearc slivers may develop, which can translate and rotate decoupled from the rest of the continent by forearc or intra-arc faults systems [e.g., Fitch, 1972; Jarrard, 1986; Beck et al., 1993; Wallace et al., 2004; McCaffrey et al., 2007].

The south-central Chile margin has been the locus of several great subduction earthquakes in the past centuries, particularly the giant 1960 Valdivia event that reached moment magnitude $\left(M_{w}\right) 9.5$ (Figure 1a), the largest recorded instrumentally [Kanamori, 1977]. The region adjacent to the 1960 event ruptured last during the 1835 Concepción earthquake, which had an estimated magnitude of 8.5 [Lomnitz, 2004]. Several modeling studies constrained by GPS data have shown that the region of the 1960 earthquake is still in the postseismic phase whereas the region of the 1835 event is in the interseismic period [Klotz et al., 2001; Khazaradze et al., 2002; Ruegg et al., 2002; Hu et al., 2004]. Several active faults have been described in the Valdivia and Concepción regions [Melnick and Echtler, 2006], some of which are associated with clusters of crustal seismicity (Figure 1) [Haberland et al., 2006; Melnick et al., 2006a]. In this study, we focus on the overlapping segment boundary between the 1960 and 1835 earthquake rupture zones. We use GPS data and finite-element models with geometrical constraints given by various geophysical data to quantify the motion of upper plate faults and to address their role on the kinematics of the forearc. We find that numerical models that introduce faulting in the upper plate better reproduce the surface velocity field derived from GPS observations. 


\section{Seismotectonic Setting}

The Chile margin is formed by oblique subduction of the Nazca oceanic plate under the South American continent at a present-day convergence rate of $66 \mathrm{~mm} / \mathrm{yr}$ [Angermann et al., 1999; Kendrick et al., 2003]. Along the Chile margin, repeated historical earthquake ruptures have defined major seismotectonic segments [Lomnitz, 2004]. In south-central Chile, the adjacent Concepción and Valdivia segments have generated several large-magnitude events described in the $\sim 500$-year-long historical record [Lomnitz, 2004; Cisternas et al., 2005]. The northern Concepción segment (35-37.5 S) (Figure 1a) ruptured last in 1835 [Darwin, 1839], with an earthquake of magnitude 8.5 [Lomnitz, 2004]. The southern Valdivia 1960 segment $\left(37.5-46^{\circ} \mathrm{S}\right)$, in turn, ruptured last during the great 1960 Chile earthquake. This event ruptured about $1000 \mathrm{~km}$ of the Nazca-South America plate boundary involving up to $40 \mathrm{~m}$ of fault slip resulting in up to $5.7 \mathrm{~m}$ of vertical coastal uplift [Plafker and Savage, 1970; Barrientos and Ward, 1990]. At present, these segments are thought to be in different phases of the seismic cycle [Barrientos et al., 1992; Klotz et al., 2001; Ruegg et al., 2002]. The deformation pattern in the 1835 earthquake segment has been interpreted to represent strain accumulation due to locking of the megathrust during the interseismic phase [Ruegg et al., 2002]. In turn, surface deformation in the 1960 earthquake segment has been thought to include the effects of protracted postseismic mantle rebound in addition to locking of the seismogenic zone [Khazaradze et al., 2002; Hu et al., 2004]. This interpretation arises from the fact that inland sites (along the intra- and back-arc zones) move in the opposite direction to coastal sites [Klotz et al., 2001; Wang et al., 2007]. 
The Arauco-Nahuelbuta forearc block is formed by the Arauco Peninsula, a major promontory along South America's Pacific coast and the Nahuelbuta Range, an abnormally-high segment of the Coastal Cordillera (Figure 1a). Here, active crustal faults have been mapped and described based on deformed coastal geomorphic features, seismicreflection profiles, and microseismicity [Melnick and Echtler, 2006; Melnick et al., 2008]. Clusters of shallow seismicity (2-25 km depth) [Bohm et al., 2002; Haberland et al., 2006] occur in the forearc along these crustal faults (Figure 1). In the Arauco bay, the NEstriking and seaward-dipping Santa María reverse fault is rooted in the interplate zone and reaches a depth of $2 \mathrm{~km}$ from the surface, where it propagates an anticline [Melnick et al., 2006a]. Focal mechanisms indicate mainly reverse slip with minor dextral strikeslip component along this fault [Bruhn, 2003]. The NW-striking Lanalhue fault system is another major deep-reaching and seismically-active structure running along the southern flank of the Nahuelbuta Range (Figures 1a and 1c). Heterogeneous focal mechanisms of shallow events along the Lanalhue fault system have been attributed to forearc fragmentation and stress distribution [Haberland et al., 2006]. A Permian mylonitic shear zone is associated to this regional-scale fault system, which bounds two main basement units, leading Glodny et al. [2008] to characterize it as an inherited, crustal-scale feature of the margin.

The Liquiñe-Ofqui fault zone (LOFZ) is a major active strike-slip system that straddles the volcanic arc of south-central Chile, accommodating oblique plate convergence [e.g., Lavenu and Cembrano, 1999; Rosenau et al., 2006] (Figure 1a). The forearc sector adjacent to the LOFZ has been described as a northward translating sliver -the Chiloé blockdecoupled from stable South America, as shown by geological [Rosenau et al., 2006] and 
GPS data [Wang et al., 2007]. In the Arauco-Nalhuebuta block, deformed Pliocene and Pleistocene sediments, patterns of fission-track ages, and folded Pleistocene marine terraces indicate margin-parallel shortening [Melnick et al., 2008]. This shortening has been interpreted as a result of northward motion of the Chiloé block, which is bounded at its northern, leading edge by the Lanalhue fault.

\section{Methods}

\subsection{GPS observation}

We present horizontal GPS velocities from 16 new campaign sites, 3 of them originally installed in the frame of the SAGA network [Klotz et al., 2001], and 3 continuous GPS stations operated by the TIGO Observatory and the University of Concepción. The sites were observed up to nine times over a 4-year time span (Table 1). Each site was occupied for at least 48 consecutive hours, but preferentially for 72 hours.

GPS data was processed using the Bernese Software Version 5.0. Processing strategies were adopted from the double-difference processing routine of Dach et al. [2007]. Satellite orbits and weekly Earth rotation parameters were introduced from the global solution of the Center for Orbit Determination in Europe (CODE, Analysis Center of IGS) [Schaer et al., 2006]. The double difference ambiguities were resolved using the quasi-ionospherefree strategy by processing the baselines separately. The site coordinates were estimated together with troposphere parameters, 12 Zenith path delays per day, and one set of horizontal gradient parameters per day. Processing of our campaign network included seven IGS stations, three of them (BRAZ, KOUR and LPGS) located in the stable part of the South American continent (i.e., cratonic shield in Brazil and Argentina). In a first step, daily normal equations without constraints on the coordinates were calculated. In 
a second step, daily normal equations were combined and site velocities were estimated. The solutions were obtained by a No-Net-Translation condition imposed on the ITRF2000 reference coordinates and velocities [Altamimi et al., 2002]. The daily repeatabilities of the coordinates for subsequent epochs were in the range of 1-2 $\mathrm{mm}$. In a third step, the site velocities were calculated with respect to a stable South American reference frame. For this calculation, the Euler vector of the stable part of the South American continent was derived with respect to the ITRF2000 reference. We obtained the final vectors by subtracting the stable-South American angular velocity from the ITRF2000 velocities of our data. The reference frame is defined with precision better than $1 \mathrm{~mm}$ for the horizontal components.

Our final solution was combined with previously published velocities in the study area [Klotz et al., 2001; Ruegg et al., 2008]. In order to make both data sets compatible, we transformed the ITRF2000 velocity solutions of Ruegg et al. [2008] to our South American reference frame. This transformation was based on the same approach used for the datum definition of our velocities and results in a horizontal precision better than $1 \mathrm{~mm} / \mathrm{yr}$.

In order to further explore our data, we calculated the principal horizontal axes of infinitesimal strain using the grid_strain Matlab program [Teza et al., 2008]. The strain was computed over a regular grid of $0.5^{\circ}$ size. Rotations with respect to a downward positive vertical axis with clockwise positive sense were computed from the modeling residuals with the software SSPX [Allmendinger et al., 2007]. 


\subsection{Finite element modeling}

\subsubsection{Modeling setup}

Interseismic deformation and the effect of a crustal fault were modeled with the finite element method (FEM) using the ANSYS ${ }^{\circledR}$ Academic Research, v. 11.0 software. The advantage of this method is its flexibility; it can incorporate complex geometry structures and heterogeneous material properties.

The three dimensional spherical models are constrained by kinematic boundary conditions (Equation in Appendix A). Models include topography and bathymetry [Smith and Sandwell, 1997] and the best available geometry of the slab and continental Moho based on the forward modeling of the gravity field of Tassara et al. [2006]. In our study region, this modeling used geometrical constraints given by seismic reflection and refraction profiles [Krawczyk et al., 2006; Groß et al., 2007], as well as microseismicity and tomography derived from local seismological networks [Haberland et al., 2006; Lange et al., 2007], and material properties given by surface geology [Sernageomin, 2003].

Our FEM models are composed of 10-node tetrahedral-shaped elements. These elements have a quadratic displacement behavior, and are well suited to model irregular meshes. Element size is between 1 and $5 \mathrm{~km}$ in the fault zones and $10 \mathrm{~km}$ in the rest of the upper crust, whereas in the oceanic crust and mantle it is 10 and $50 \mathrm{~km}$, respectively (Figure $2 a)$.

The models extend from $76-60^{\circ} \mathrm{W}$ to $35-45^{\circ} \mathrm{S}$ and to a depth of $\sim 500 \mathrm{~km}$, in order to omit boundary effects. The models consist of an elastic upper plate, an elastic subducting plate, and a viscoelastic mantle (Figure 2a). The thickness of the elastic oceanic plate is set to $30 \mathrm{~km}$ [ Watt and Zhong, 2000]. We specified a Young's modulus of $100 \mathrm{GPa}, 120$ 
$\mathrm{GPa}$ and $160 \mathrm{GPa}$, for the oceanic, continental, and mantle layers, respectively, following Hu et al. [2004]. The Poisson ratio is set to 0.25 for the entire rock system, as adopted by similar model studies in the region [Khazaradze et al., 2002; Hu et al., 2004; Wang et al., 2007]. The mantle viscosity is assumed to be $2.5 \times 10^{19} \mathrm{~Pa}$ s following the sensitivity results from $\mathrm{Hu}$ et al. [2004].

Interseismic deformation is simulated using the back-slip method [Savage, 1983]. In this approach a virtual slip in a reverse sense to the plate motion is imposed on the fault interplate. We implemented this method using the split-node technique [Melosh and Raefsky, 1981], which allows to introduce fault displacements into FEM simulating the doublecouple acting on the fault. We assume that the seismogenic zone of the plate interface is fully locked following previous studies in the region [Klotz et al., 2001; Khazaradze et al., 2002; Ruegg et al., 2002; Hu et al., 2004; Ruegg et al., 2008; Wang et al., 2007]. Thus, we imposed the amount of plate convergence during one year $(6.6 \mathrm{~cm})$ as the back slip value, using the $3 \mathrm{D}$ vectors estimated from plate kinematic models along the strike of the plate interface. We introduced the calculated vectors to each pair of nodes in the interplate locked zone using linear constraint equations, defined for example for the displacement component in the $\mathrm{X}$ direction by:

$D_{X}=\sum_{i}^{N}\left[(R(i)) \times U_{X}(i)\right]$; where $U_{X}(i)$ is the displacement in the $\mathrm{X}$ direction of the node $(i), R(i)$ is the displacement ratio between each node in a pair of nodes on the plate interface and $D_{X}$ is the constant magnitude of the applied displacement, in this case the $\mathrm{X}$ component of the plate convergence rate.

The applied boundary conditions of our model are schematically shown in Figure 2b. Each node on the contact faces is duplicated. Green and blue nodes, which are part of the 
continental and oceanic plates, respectively, are initially located at the same coordinates. The nodes are forced to remain on the fault and consequently can only slide along the interface. After applying the constraint equations, nodes at both sides of the fault are equally displaced but in opposite directions.

The seismogenic part of the plate interface consists of a fully locked area bounded by upand downdip transition zones (Figure 2b). The downdip transition zone extends $10 \mathrm{~km}$ vertically below the locked zone and the slip tapers linearly to zero. Outside the transition zone, each pair of nodes on the interface is coupled together sharing the same degrees of freedom. Above the updip limit, nodes can slip freely along the interface. Displacements perpendicular to each boundaries of the model were fixed to zero. The upper surface of the model is assumed to be stress-free, and therefore no constraints were applied.

We must emphasize that the solutions to our modeling problem are nonunique. The major uncertainties may be associated to: (1) errors in the geometry of the subduction zone, which are rarely reported in the geophysical data that we have used and difficult to estimate; (2) the degree of plate coupling and its along- and across-strike variability [e.g., Chlieh et al., 2008]; and (3) heterogeneity in material properties. We adopt conservative estimates for these parameters following previous modeling studies that have used similar techniques.

\subsubsection{Crustal fault modeling}

In a second step, we introduced the effect of the Santa María fault on the interseismic model. We model this fault based on its documented active behavior, its relatively wellknown subsurface geometry [Bookhagen et al., 2006; Melnick et al., 2006a] and on the residuals of the interseismic model (results in section 4.2.1). The Santa María fault is 
modeled as a blind fault, which extends from the interplate zone to a depth of $2 \mathrm{~km}$ (Figure 2a), as constrained by seismicity and seismic reflection profiles.

The fault plane is introduced by contact-target surface elements [Saeed,2007]. Following the split-node fault technique, we define the fault as two planes with identical distribution of nodes. Constraint equations are applied to introduce the slip rate on the fault. Contacttarget elements obey the Coulomb friction criteria; surfaces can accumulate shear stresses up to a certain magnitude before they start sliding (Equations in Appendix B). The contact algorithms use the penalty stiffness method, with a contact option for closed gap, penetration reduction, exclusion of initial geometrical effect and no separation [Saeed, 2007]. Thus, contact elements are prevented from penetrating the target surface but permitted to slide along the fault.

\subsubsection{Sensitivity analysis}

Sensitivity analyses were performed for the unknown input parameters of the FEM modeling using probabilistic and optimization methods. For the probabilistic method, we used the Monte Carlo simulation, from which the variability of the input parameters and their influence on the results were determined. The sensitivity results are collected in the correlation matrix of the input parameters versus the output variables. An optimization analysis was performed in order to estimate the best values of the unknown input parameters, which minimize the root-mean square (RMS) between the model results and the GPS vectors.

In the interseismic sensitivity analysis, the margin was divided into 0.5-degree-long segments, in which different depths of up- and downdip limits and continental Young's 
modulus were explored. In the models that included a crustal fault, the slip rate of the fault and its coefficient of friction were defined as unknown input parameters.

\section{Results}

\subsection{GPS velocities}

GPS site velocities calculated with respect to a stable South American reference frame are shown in Figure 3 and Table 1 . The data cover the entire onshore forearc of the south-central Chile margin between 36 and $39.5^{\circ} \mathrm{S}$. In the northern part of the AraucoNahuelbuta block, GPS vectors are nearly parallel to the direction of plate convergence and their magnitudes progressively decrease toward the arc. The sites on the hanging wall of the Santa María fault have the highest margin-normal velocities of up to $40 \mathrm{~mm} / \mathrm{yr}$, diminishing to $30 \mathrm{~mm} / \mathrm{yr}$ at sites $30 \mathrm{~km}$ inland on the footwall (Figure 4). In contrast, the margin-parallel velocity of hanging wall sites is lower with respect to the counterparts in the footwall. Principal shortening axes are roughly perpendicular to the Santa María fault, decreasing abruptly in magnitude away from the fault (Figure 3).

In general, GPS vectors on the southern part of the Arauco-Nahuelbuta block have lower magnitudes than their counterparts to the north. In the proximity of the Lanalhue fault, vectors have heterogeneous magnitudes and orientations (Figures 3 and 4). The coastal sites have the highest margin-normal velocities of $32 \mathrm{~mm} / \mathrm{yr}$, which decrease rapidly inland to $18 \mathrm{~mm} / \mathrm{yr}$ across a distance of only $10 \mathrm{~km}$. An opposite effect is observed in the marginparallel velocities, which decrease from 20 to $12 \mathrm{~mm} / \mathrm{yr}$ between Mocha Island and the mainland.

The differences in the surface velocity field along the part of the forearc under investigation permit to define two distinct sectors, the northern and southern domains. The 
boundary of these two domains is located in the center of the Arauco Peninsula at $37.5^{\circ} \mathrm{S}$ (Figure 3).

\subsection{Modeling result}

\subsubsection{Interseismic model result}

A comparison between the velocities predicted by the best-fit interseismic model and the GPS vectors is shown in Figure 5a. The model vectors agree relatively well with the GPS velocities in the northern domain, but large discrepancies appear in the southern sector. The average RMS is $3.15 \mathrm{~mm} / \mathrm{yr}$ and $14.11 \mathrm{~mm} / \mathrm{yr}$ in the northern and southern domains, respectively. GPS velocities are successfully reproduced by the interseismic model along the cross section at $37.2^{\circ} \mathrm{S}$ (Figure $5 \mathrm{~b}$ ). In this profile, a downdip depth of 46 $\mathrm{km}$ produces the lowest RMS of $2.19 \mathrm{~mm} / \mathrm{yr}$. A shallower downdip depth results in slower surface velocities, whereas a deeper limit leads to faster rates. Sensitivity results suggest that the downdip depth of the interplate locked zone has the most significant influence on the interseismic surface velocity field, whereas variations in the Young's modulus have a minor effect. A value of $100 \mathrm{GPa}$ for the continental Young's modulus provided the lowest RMS (Figure 5c). The updip transition affects mostly coastal sites and has a weak influence on the rest of the sites.

Our results imply that the locked portion of the seismogenic zone is wider in the northern domain, where the depth of the downdip limit shallows gradually southward from 49 to $45 \mathrm{~km}$ (Figure 6). A depth of $12 \mathrm{~km}$ for the updip limit was our best estimate in this domain. Because of the heterogeneity of GPS vectors in the southern domain, we relied on geophysical estimates of the up- and downdip limits based on the distribution of microseismicity and tomographic models derived from local seismic networks [Haberland 
et al., 2006; Lange et al., 2007], and from seismic reflection and refraction profiles [Groß et al., 2007]. We adopted a downdip depth of $44 \mathrm{~km}$ at $38^{\circ} \mathrm{S}$, which decreases to $40 \mathrm{~km}$ at $42^{\circ} \mathrm{S}$. Between 42 and $45^{\circ} \mathrm{S}$, the downdip depth was set to $35 \mathrm{~km}$ following Lange et al. [2007]. The depth of the updip limit was fixed at $10 \mathrm{~km}$ based on the onset of microseismicity for the entire southern domain [Haberland et al., 2006; Lange et al., 2007].

Two areas have significant residual velocities (Figure 7a). The first area is the northern coastal region in the proximity of the Santa María fault, where several sites have SWdirected residual vectors with an average RMS of $4.26 \mathrm{~mm} / \mathrm{yr}$. The second area is in the southern domain of the Arauco-Nahuelbuta block; here high magnitude residuals are directed seawards and rotate progressively in a counterclockwise sense (Figure 7b).

\subsubsection{Fault model results}

The interseismic model that includes the Santa María fault provides a better fit to the GPS observations. The average residual velocities of the near-fault sites decrease from $4.26 \mathrm{~mm} / \mathrm{yr}$ to $2.70 \mathrm{~mm} / \mathrm{yr}$ after including the crustal fault (Figure 8a). Fault deformation produces the surface velocity gradient observed in the GPS vectors near this structure (Figure 8b). Our sensitivity results suggest that the strike-slip rate along the Santa María fault has a significant effect on the surface velocity. Vertical slip rate and the coefficient of friction have a secondary effect, with a significance of about $40 \%$ with respect to the horizontal slip (Figure 8c). We obtained a dextral strike-slip rate of 6.9 $\mathrm{mm} / \mathrm{yr}$, and a reverse dip slip rate of $2.8 \mathrm{~mm} / \mathrm{yr}$. A coefficient of friction of 0.6 was the best estimate for the fault. 


\section{Discussion}

Our new GPS data show that forearc deformation exhibits heterogeneous patterns in the Arauco-Nahuelbuta block. GPS displacements can be grouped in two sectors: the northern and southern domains, which follow the rupture boundaries of two recent megathrust earthquakes: the $1835(M \sim 8.5)$ Concepción and the $1960\left(M_{w} 9.5\right)$ Valdivia events.

In the northern domain, GPS vectors are generally parallel to each other and to the direction of plate convergence, and their magnitude decrease continuously inland. This pattern has been previously interpreted as to reflect locking of the plate interface during the interseismic phase of the earthquake cycle [Klotz et al., 2001; Ruegg et al., 2002]. The residual velocity field after subtraction of the interseismic model velocities from our GPS observations shows an anomalous pattern in the coastal sites between the Santa María Island and Concepción (Figure 7a). Here, residuals are oriented parallel to the Santa María fault and reach maximum values of $\sim 6 \mathrm{~mm} / \mathrm{yr}$. This suggests that the Santa María fault is active during interseismic period, as previously proposed based on the occurrence of a cluster of crustal seismicity along the fault [Melnick et al., 2006a]. Our best-fit model including this fault in addition to locking of the megathrust incorporates vertical and dextral horizontal fault slip rates of 2.8 and $6.9 \mathrm{~mm} / \mathrm{yr}$, respectively, and a coefficient of friction of 0.6 (Figure 8c). This value of friction is in agreement with laboratory estimates [Byerlee, 1978].

Our GPS data in the entire northern domain show shortening, which we attribute to locking of the plate interface, and thus ongoing thrust-type shear of the upper plate by megathrust loading. Because no megathrust earthquakes have ruptured the Concepción segment since 1835, loading is expected to be in an advanced phase, which might promote 
thrust faulting. Thus, activity of the Santa María fault at present may be releasing part of the interseismic stress accumulated since the last great earthquake rupture.

In the southern domain, GPS vectors vary markedly in orientation and magnitude, with a much lower degree of correlation with the interseismic pattern than that observed in the northern domain (Figures 3 and 4). Based on regional GPS data and FEM models, this area has been previously interpreted as influenced by prolonged postseismic mantle rebound following the 1960 earthquake [Khazaradze et al., 2002; Hu et al., 2004].

In the northern limit of the 1960 earthquake rupture zone, the residual velocities of the interseismic model exhibit an heterogeneous pattern. Residual vectors situated north of the Lanalhue fault rotate in a clockwise mode, whereas to the south of the fault residuals rotate counterclockwise (Figure $7 \mathrm{~b}$ ). Their dissimilar magnitude and direction may result from the boundary effects between postseismic and interseismic deformation. In addition, heterogeneous mantle rebound could follow patches of variable slip during the 1960 earthquake resulting in complex patterns of surface velocity. However, modeling these processes would require detailed knowledge of the 1960 slip distribution and will be the scope of further work.

An alternative interpretation of the counterclockwise rotation pattern of residual velocities in the northern limit of the 1960 earthquake rupture may arise from a detailed inspection of regional tectonic features and fault geometries. The 1960 rupture zone seems to be coincident with the extent of the Chiloé forearc sliver, which translates parallel to the margin decoupled from stable South America by the Liquiñe-Ofqui fault zone [Melnick et al., 2008] (Figure 9). The convergence between the Chiloé forearc sliver and the AraucoNahuelbuta block is accomodated by folding and thrusting in the Arauco Peninsula as 
well as by oblique thrusting along the Lanalhue fault [Melnick et al., 2008]. Because of the oblique, NW strike of the Lanalhue fault, the northern leading edge of the Chiloé block is a triangular region expected to rotate counterclockwise as a result of marginparallel sliver translation. In contrast, regional GPS data [Klotz et al., 2001; Wang et al., 2007] as well as finite-element models [Khazaradze et al., 2002; Hu et al., 2004; Wang et al., 2007] show that rotations arising from postseismic mantle rebound at the northern limit of the 1960 earthquake rupture are dominantly clockwise and extend over a broad region between the forearc and the back-arc. Thus, because the counterclockwise rotations observed in the GPS vectors occur exclusively in a limited region between the coast and the Lanalhue fault, they may be caused by the collision of the Chiloé sliver against the Arauco-Nahuelbuta block. This collision appears to be partly accomodated by the Lanalhue fault (Figure 9).

Our model results suggest that the interplate coupling zone narrows southward along the south-central Chile margin (Figure 6). In the northern domain, the downdip limit of coupling reaches a depth of $49 \mathrm{~km}$ at $36^{\circ} \mathrm{S}$ shallowing to $45 \mathrm{~km}$ at $37.5^{\circ} \mathrm{S}$. These values are in agreement with the intersection of the slab with the continental Moho, determined independently by tomography [Bohm et al., 2002; Haberland et al., 2006], seismic reflection and refraction profiles [Lüth et al., 2003; Krawczyk et al., 2006; Groß et al., 2007], and modeling of gravity data [Tassara et al., 2006]. In the southern domain, the downdip limit is at $44 \mathrm{~km}$ depth at $38^{\circ} \mathrm{S}$ and shallows to $40 \mathrm{~km}$ at $42^{\circ} \mathrm{S}$. This change in downdip depths between the 1835 and 1960 earthquake-rupture segments is likely a result of the gradual variation in age of the incoming plate along the trench. As slab age decreases southward, heat-flow increases resulting in narrower coupling [Wang et al., 2007]. Our 
statistically-calculated updip limit for the northern domain is consistent with a depth of $12 \mathrm{~km}$, which coincides with the prediction of Grevemeyer et al. [2003] based on heat-flow measurements.

Along the 1960 rupture zone segment, the margin-parallel component of oblique plate convergence is partly accommodated by the LOFZ [Rosenau et al., 2006]. GPS data show that this structure absorbs about $30 \%$ of the margin-parallel component [Wang et al., 2007]. However, across the northern limit of the 1960 segment, where the LOFZ terminates and where our GPS data show counterclockwise rotations in the coastal region, the degree of strain partition along the margin decreases considerably. This gradient in the degree of partitioning has been deduced from changes in the kinematics of Quaternary faults along the fore-, intra-, and back-arc regions [Melnick et al., 2006b] (Figure 9). Our modeling results for the Santa María fault suggest a dextral strike-slip rate of $6.8 \mathrm{~mm} / \mathrm{yr}$, which given its strike would result in about $6 \mathrm{~mm} / \mathrm{yr}$ of margin-parallel motion, equivalent to about $25 \%$ of the margin-parallel component of plate convergence. This would support the previous proposition of a gradient in the degree of strain partitioning: in the southern 1960 earthquake domain, part of the margin-parallel component is accommodated along the intra-arc zone by the LOFZ; whereas in the northern 1835 earthquake domain, lower magnitudes of margin-parallel motion are distributed across several faults located in the forearc, such as the Santa María fault, as well as in the intra- and back-arc domains, thus suggesting a lower degree of partitioning.

\section{Conclusions}

New GPS data have revealed heterogeneous deformation patterns along the southcentral Chile forearc. Variations are spatially correlated with the rupture limits of the 
two past megathrust earthquakes, the $1835 M \sim 8.5$ Concepción and $1960 M_{w} 9.5$ Valdivia events. Finite-element models of interseismic deformation including complex crustal geometries, constrained by various geophysical data sets, are unable to fully reproduce the heterogeneous GPS deformation patterns. In the northern 1835 earthquake domain, interseismic models that include the Santa María fault, a crustal-scale reverse/dextral structure, better reproduce the GPS observations. In the southern domain, in turn, the interseismic model residuals show counterclockwise rotations, which could reflect either postseismic relaxation of the mantle at the northern edge of the 1960 rupture zone or activity of the seismically-active Lanalhue fault, or both.

Our study suggests that crustal-scale faults rooted in the interplate seismogenic zone may affect the surface deformation field during the interseismic phase of the earthquake cycle. This effect, though local, might have a significant amplitude. We propose that these structures may release part of the contractional strain that accummulates during interseismic locking of the megathrust, affecting the surface velocity field. Thus, active faults rooted in the plate interface should be considered when inverting geodetic data to constrain locking depths of the seismogenic zone.

\section{Appendix A: Elastic equation}

The elastic behavior of the oceanic and continental crust, respectively, is described by:

$$
\operatorname{div} \sigma=-\underline{\mathrm{f}},
$$

where $\sigma(\underline{\mathrm{u}})=\lambda \operatorname{tr}(\epsilon(\underline{\mathrm{u}})) \mathrm{id}+2 \mu \epsilon(\underline{\mathrm{u}})$ is the stress, $\underline{\mathrm{f}}$ the volume force, $\epsilon(\underline{\mathrm{u}})=\left(\nabla \underline{\mathrm{u}}+(\nabla \underline{\mathrm{u}})^{T}\right) / 2$ the strain, and $\lambda$ and $\mu$ the Lamé constants. The Young's modulus and Poisson's ratio are expressed as $E=\frac{\mu(3 \lambda+2 \mu)}{\lambda+\mu}$ and $\nu=\frac{\lambda}{2(\lambda+\mu)}$, respectively. 


\section{Appendix B: Contact interface}

For the contact let $g$ denote the gap between two surfaces, then the contact pressure $F_{n}$ reads:

$$
F_{n}= \begin{cases}t_{n}-e_{n} \cdot g & : g<0 \\ t_{n} \cdot e^{-e_{n} / t_{n} \cdot g} & : g \geq 0\end{cases}
$$

where $t_{n}$ estimates the contact force and $e_{n}$ is the penalty stiffness. The force for the Coulomb friction reads:

$$
F_{f}= \begin{cases}K \cdot u_{t} & : K \cdot u_{t} \leq \mu \cdot F_{n} \text { (sticking), } \\ \mu \cdot F_{n} & : K \cdot u_{t}>\mu \cdot F_{n} \text { (sliding), }\end{cases}
$$

where $u_{t}$ is the tangential displacements, $\mu$ the friction coefficient, and $K$ the sticking stiffness.

Acknowledgments. This work was supported by the Helmholtz Centre Potsdam in the framework of the TIPTEQ project (from The Incoming Plate to megaThrust EarthQuakes). Marcos Moreno gratefully acknowledges a scholarship granted by the German Academic Exchange Service (DAAD). Our special thanks go to: Jan Bolte, Matt Miller, Marcelo Contreras, Volker Grund, Junping Chen, Irina Rogozhina, Juan Carlos Baez, Andrés Tassara, Viktoria Georgieva, Matías Sánchez, Jorge Ávila for fruitful cooperation.

\section{References}

Allmendinger, R., R. Reilinger, and J. Loveless (2007), Strain and Rotation Rate from GPS in Tibet, Anatolia, and the Altiplano, Tectonics, 26, TC3013, doi:10.1029/ $2006 \mathrm{TC} 002030$.

Altamimi, Z., P. Sillard, and C. Boucher (2002), ITRF2000: A new release of the International Terrestrial Reference frame for earth science application, J. Geophys. Res., 107(B10), 2214, doi:10.1029/2001JB000561. 
Angermann, D., J. Klotz, and C. Reigber (1999), Space-geodetic estimation of the NazcaSouth America Euler vector, Earth Planet. Sci. Lett., $171(3), 329-334$.

Barnes, P. M., A. Nicol, and T. Harrison (2002), Late Cenozoic evolution and earthquake potential of an active listric thrust complex above the Hikurangi subduction zone, New Zealand, Geol. Soc. Am. Bull., 114(11), 1379-1405.

Barrientos, S., and S. Ward (1990), The 1960 Chile earthquake: inversion for slip distribution from surface deformation, Geophys. J. Int., 103(3), 589-598.

Barrientos, S., G. Plafker, and E. Lorca (1992), Postseismic coastal uplift in southern Chile, Geophys. Res. Lett., 19(7), 701-704.

Beck, M., C. Rojas, and J. Cembrano (1993), On the nature of buttressing in marginparallel strike-slip fault systems, Geology, 21(8), 755-758.

Bohm, M. (2004), 3-D local earthquake tomography of the southern Andes between $36^{\circ}$ and $40^{\circ} \mathrm{S}$, Ph.d. thesis, Free University.

Bohm, M., S. Lüth, H. Echtler, G. Asch, K. Bataille, C. Bruhn, A. Rietbrock, and P. Wigger (2002), The Southern Andes between $36^{\circ} \mathrm{S}$ and $40^{\circ} \mathrm{S}$ latitude: seismicity and average velocities, Tectonophysics, 356, 275-289.

Bookhagen, B., H. P. Echtler, D. Melnick, M. R. Strecker, and J. Q. G. Spencer (2006), Using uplifted Holocene beach berms for paleoseismic analysis on the Santa María Island, south-central Chile, Geophys. Res. Lett., 33, L15302, doi:10.1029/2006GL026734. Bruhn, C. (2003), Momententensoren hochfrequenter Ereignisse in Sudchile, Ph.d. thesis, University of Potsdam.

Byerlee, J. (1978), Friction of rocks, Pure Appl. Geophys., 116, 615-626. 
Chlieh, M., J. Avouac, K. Sieh, D. Natawidjaja, and J. Galetzka (2008), Heterogeneous coupling of the Sumatran megathrust constrained by geodetic and paleogeodetic measurements, J. Geophys. Res., 113, B05305, doi:10.1029/2007JB004981.

Cisternas, M., B. Atwater, F. Torrejón, Y. Sawai, G. Machuca, M. Lagos, A. Eipert, C. Youlton, I. Salgado, T. Kamataki, M. Shishikura, C. Rajendran, J. Malik, Y. Rizal, and M. Husni (2005), Predecessors of the giant 1960 Chile earthquake, Nature, $437(7057), 404-407$.

Dach, R., U. Hugentobler, P. Fridez, and M. Meindl (2007), Bernese GPS Software 5.0, Astron. Inst. Univ. of Berne, Berne, Switzerland, available at http://www.bernese.unibe.ch/docs/DOCU50draft.pdf.

Darwin, C. (1839), Journal and Remarks. 1832-1836. Volume III of Narrative of the Surveying Voyages of His Majesty's Ships Adventure and Beagle between the Years 1826 and 1836, Describing their Examination of the Southern Shores of South America, and the Beagle's Circumnavig, 3, 370-381.

Fitch, T. (1972), Plate convergence, transcurrent faults, and internal deformation adjacent to southeast Asia and the western Pacific, J. Geophys. Res., 7r7(23), 4432-4460.

Glodny, J., H. Echtler, S. Collao, M. Ardiles, P. Buron, and O. Figueroa (2008), Differential Late Paleozoic active margin evolution in south-central Chile (37-40 $\mathrm{S})$ - The Lanalhue Fault Zone , J. South Amer.Earth Sc., doi:10.1016/j.jsames.2008.06.001, in press.

Grevemeyer, I., J. Diaz-Naveas, C. Ranero, and H. Villinger (2003), Heat flow over the descending Nazca plate in central Chile, $32^{\circ} \mathrm{S}$ to $41^{\circ} \mathrm{S}$ : Observations from ODP Leg 202 and the occurrence of natural gas hydrates, Earth Planet. Sci. Lett., 213(3-4), 285-298. 
Groß, K., U. Micksch, T. r. group, and S. team (2007), The reflection seismic survey of project TIPTEQ-the inventory of the Chilean subduction zone at $38.2^{\circ} \mathrm{S}$, Geophys. J. Int., 172(2), 565-571, doi:10.1111/j.1365-246x.2007.0.3680.x.

Haberland, C., A. Rietbrock, D. Lange, K. Bataille, and S. Hofmann (2006), Interaction between forearc and oceanic plate at the south-central Chilean margin as seen in local seismic data, Geophys. Res. Lett., 33, L23302, doi:10.1029/2006GL028189.

Hsu, Y. J., M. Simons, J. P. Avouac, J. Galeteka, K. Sieh, M. Chlieh, D. Natawidjaja, L. Prawirodirdjo, and Y. Bock (2006), Frictional afterslip following the 2005 NiasSimeulue earthquake, Sumatra, Science, 312(5782), 1921-1926.

Hu, Y., K. Wang, J. He, J. Klotz, and G. Khazaradze (2004), Three-dimensional viscoelastic finite element model for postseismic deformation of the great 1960 Chile earthquake, Geophys. Res. Lett., $109(12), 1-14$.

Hyndman, R., and K. Wang (1995), The rupture zone of Cascadia great earthquakes from current deformation and the thermal regime, J. Geophys. Res., 100, 22,133-22,154.

Jarrard, R. D. (1986), Terrane motion by strike-slip faulting of forearc slivers, Geology, $14(9), 780-783$.

Kanamori, H. (1977), The energy release in great earthquakes, J. Geophys. Res., 82(20), $2981-2987$.

Kendrick, E., M. Bevis, R. Smalley Jr., B. Brooks, R. Vargas, E. Lauría, and L. Fortes (2003), The Nazca-South America Euler vector and its rate of change, J. South Am. Earth Sci., 16(2), 125-131.

Khazaradze, G., K. Wang, J. Klotz, Y. Hu, and J. He (2002), Prolonged post-seismic deformation of the 1960 great Chile earthquake and implications for mantle rheology, 
Geophys. Res. Lett., 29(22), 7-1.

Klotz, J., G. Khazaradze, D. Angermann, C. Reigber, R. Perdomo, and O. Cifuentes (2001), Earthquake cycle dominates contemporary crustal deformation in central and southern Andes, Earth Planet. Sci. Lett., 193, 437-446.

Krawczyk, C., J. Mechie, S. Lueth, Z. Tasarova, P. Wigger, M. Stiller, H. Brasse, H. Echtler, M. Araneda, and K. Bataille (2006), Geophysical signatures and active tectonics at the south-central chilean margin, in The Andes - Active Subduction Orogeny, vol. 1, edited by O. Oncken, G. Chong, G. Franz, P. Giese, H.-J. Götze, V. Ramos, M. Strecker, and P. Wigger, pp. 171-192, Springer-Verlag, Berlin Heidelberg New York. Lange, D., A. Rietbrock, C. Haberland, K. Bataille, T. Dahm, F. Tilmann, and E. R. Flueh (2007), Seismicity and geometry of the south Chilean subduction zone $\left(41.5^{\circ} \mathrm{S}-\right.$ 43.5 ${ }^{\circ}$ ): Implications for controlling parameters, Geophys. Res. Lett., 34, L06311, doi: 10.1029/2006GL029190.

Lavenu, A., and J. Cembrano (1999), Compressional- and transpressional-stress pattern for Pliocene and Quaternary brittle deformation in fore arc and intra-arc zones (Andes of Central and Southern Chile), J. Struct. Geology, 21(12), 1669-1691.

Lomnitz, C. (2004), Major earthquakes of Chile: a historical survey, 1535-1960, Seismol. Res. Lett., $75(3), 368-378$.

Lüth, S., P. Wigger, M. Araneda, G. Asch, K. Bataille, M. Bohm, C. Bruhn, P. Giese, S. Lüth, J. Quezada, A. Rietbrock, and P. Wigger (2003), A crustal model along 39 S from a seismic refraction profile-ISSA 2000, Rev. Geol. Chile, 30(1), 83-94.

Mazzotti, S., X. Le Pichon, P. Henry, and S. I. Miyazaki (2000), Full interseismic locking of the Nankai and Japan-west Kurile subduction zones: An analysis of uniform 
elastic strain accumulation in Japan constrained by permanent GPS, J. Geophys. Res., $105(\mathrm{~B} 6), 13,159-13,177$.

McCaffrey, R., and C. Goldfinger (1995), Forearc deformation and great subduction earthquakes: Implications for Cascadia offshore earthquake potential, Science, 267(5199), 856-859.

McCaffrey, R., A. Qamar, R. King, R. Wells, G. Khazaradze, C. Williams, C. Stevens, J. Vollick, and P. Zwick (2007), Fault locking, block rotation and crustal deformation in the Pacific Northwest, Geophys. J. Int., $169(3)$, 1315-1340, doi:10.1111/j.1365-246X. 2007.03371.x.

Melnick, D., and H. Echtler (2006), Morphotectonic and geologic digital map compilations of the south-central Andes $\left(36^{\circ} \mathrm{S}-42^{\circ} \mathrm{S}\right)$, in The Andes - Active Subduction Orogeny, Frontiers in Earth Sciences, vol. 1, edited by O. Oncken, G. Chong, G. Franz, P. Giese, H.-J. Götze, V. Ramos, M. Strecker, and P. Wigger, pp. 565-568, Springer-Verlag, Berlin Heidelberg New York.

Melnick, D., B. Bookhagen, H. Echtler, and M. Strecker (2006a), Coastal deformation and great subduction earthquakes, Isla Santa María, Chile (37 S), Geol. Soc. Am. Bull., 118(11/12), 1463-1480.

Melnick, D., F. Charlet, H. Echtler, and M. De Batist (2006b), Incipient axial collapse of the Main Cordillera and strain partitioning gradient between the Central and Patagonian Andes, Lago Laja, Chile, Tectonics, $25(5)$, TC5004.

Melnick, D., B. Bookhagen, M. Strecker, and H. Echtler (2008), Segmentation of subduction earthquake rupture zones from forearc deformation patterns over hundreds to millions of years, Arauco Peninsula, Chile, J. Geophys. Res., revised version submitted. 
Melosh, H. J., and A. Raefsky (1981), A simple and efficient method for introducing faults into finite element computations, Bull. Seismol. Soc. Am., 71(5), 1391-1400.

Park, J.-O., T. Tsuru, S. Kodaira, P. Cummins, and Y. Kaneda (2002), Splay fault branching along the Nankai subduction zone, Science, 297(5584), 1157-1160.

Plafker, G. (1972), Alaskan earthquake of 1964 and Chilean earthquake of 1960 - Implications for arc tectonics, J. Geophys. Res., 77(5), 901-925.

Plafker, G., and J. Savage (1970), Mechanism of the Chilean earthquake of May 21 and 22, 1960, Geol. Soc. Am. Bull., 81, 1001-1030.

Rosenau, M., D. Melnick, and H. Echtler (2006), Kinematic constraints on intra-arc shear and strain partitioning in the Southern Andes between $38^{\circ} \mathrm{S}$ and $42^{\circ} \mathrm{S}$ latitude, Tectonics, 25(4), TC4013.

Ruegg, J., J. Campos, R. Madariaga, E. Kausel, J. de Chabalier, R. Armijo, D. Dimitrov, I. Georgiev, and S. Barrientos (2002), Interseismic strain accumulation in south central Chile from GPS measurements, 1996-1999, Geophys. Res. Lett., 29(11), 12-1.

Ruegg, J. C., A. Rudloff, C. Vigny, R. Madariaga, J. Dechabalier, J. Campos, E. Kausel, S. Barrientos, and D. Dimitrov (2008), Interseismic strain accumulation measured by gps in south central chile seismic gap, Phys. Earth Planet Inter., in press.

Rundle, J. B. (1978), Viscoelastic crustal deformation by finite quasi-static sources, J. Geophys. Res., 83(B12), 5937-5946.

Saeed, M. (2007), Finite Element Analysis: theory and application with ANSYS, 3rd ed., Prentice Hall, Minnesota State University-Mankato.

Savage, J. (1983), A dislocation model of strain accumulation and release at a subduction zone, J. Geophys. Res., 88(B6), 4984-4996. 
Savage, J. C., M. Lisowski, and W. H. Prescott (1981), Strain accumulation across the Denali fault in the Delta River canyon, Alaska, J. Geophys. Res., 86(B2), 1005-1014.

Schaer, S., U. Hugentobler, R. Dach, M. Meindl, H. Bock, C. Urschl, A. Gäde, M. Ploner, L. Ostini, P. Fridez, and G. Beutler (2006), GNSS analysis at code [online], ESA ESOC, http://nng.esoc.esa.de/ws2006/GNSS8.pdf. Accessed 6 Oct 2006.

Sernageomin (2003), Geologic map of Chile: Digital version 1:1.000.000, Santiago, Chile. Smith, W. H. F., and D. Sandwell (1997), Global Sea Floor Topography from Satellite Altimetry and Ship Depth Soundings, Science, 277(5334), 1956 - 1962, doi:10.1126/ science.277.5334.1956.

Tassara, A., H. Götze, S. Schmidt, and R. Hackney (2006), Three-dimensional density model of the Nazca plate and the Andean continental margin, J. Geophys. Res., 111, B09404, doi:10.1029/2005JB003976.

Teza, G., A. Pesci, and A. Galgaro (2008), Grid_strain and grid strain3: software packages for strain field computation in 2D and 3D environments, Comput. Geosci., 34(9), 11421153, doi:10.1016/j.cageo.2007.07.006.

Thatcher, W. (1984), The earthquake deformation cycle, recurrence, and the time- predictable model., J. Geophys. Res., 89(B7), 5674-5680.

Thatcher, W., and J. Rundle (1979), A model for the earthquake cycle in underthrust zones., J. Geophys. Res., 84 (B10), 5540-5556.

Tse, S. T., and J. R. Rice (1986), Crustal earthquake instability in relation to the depth variation of frictional slip properties, J. Geophys. Res, 91, 9452-9472.

Wallace, L., J. Beavan, R. McCaffrey, and D. Darby (2004), Subduction zone coupling and tectonic block rotations in the North Island, New Zealand, J. Geophys. Res., 109, 
B12406, doi:10.1029/2004JB003241.

Wang, K., Y. Hu, M. Bevis, E. Kendrick, R. Smalley Jr., R. Barriga-Vargas, and E. Lauría (2007), Crustal motion in the zone of the 1960 Chile earthquake: Detangling earthquake-cycle deformation and forearc-sliver translation, Geochem. Geophys. Geosyst., 8(Q10010), doi:10.1029/2007GC001721.

Watt, A., and S. Zhong (2000), Observations of flexure and the rheology of oceanic lithosphere, Geophys. J. Int., (142), 855-875. 
Table 1. GPS station locations and calculated horizontal velocities

\begin{tabular}{lccccccccc}
\hline ID & Longitude & Latitude & $\begin{array}{c}V_{e} \\
\mathrm{~mm} / \mathrm{yr}\end{array}$ & $\begin{array}{c}1 \sigma \\
\text { error }\end{array}$ & $\begin{array}{c}V_{n} \\
\mathrm{~mm} / \mathrm{yr}\end{array}$ & $\begin{array}{c}1 \sigma \\
\text { error }\end{array}$ & $\begin{array}{c}\text { Correl. } \\
\text { coeff }\end{array}$ & $\begin{array}{c}\text { Num. } \\
\text { Surveys }\end{array}$ & $\begin{array}{c}\text { Time } \\
\text { Epochs }\end{array}$ \\
\hline AROA & -72.771 & -36.736 & 28.5 & 1.37 & 10.3 & 1.19 & -0.45 & 9 & $2002.6-2005.4$ \\
CACH & -73.211 & -36.772 & 34.4 & 1.26 & 9.4 & 2.01 & -0.66 & 4 & $2002.8-2007.0$ \\
CLAS & -72.668 & -39.285 & 13.9 & 1.80 & 3.7 & 1.09 & -0.38 & 2 & $2003.9-2005.9$ \\
IMOR & -73.664 & -37.723 & 19.1 & 1.67 & 17.6 & 2.20 & -0.70 & 5 & $2003.9-2007.1$ \\
LAJA & -72.52 & -37.256 & 25.7 & 2.74 & 3.9 & 0.55 & -0.21 & 3 & $2003.9-2007.0$ \\
LEBU & -73.668 & -37.596 & 34.8 & 0.47 & 16.0 & 0.13 & -0.66 & 4 & $2003.9-2007.1$ \\
MOCH & -73.905 & -38.410 & 32.9 & 1.52 & 8.1 & 2.12 & -0.70 & 6 & $2002.7-2007.1$ \\
NACI & -72.689 & -37.607 & 18.0 & 2.56 & 4.6 & 0.54 & -0.31 & 4 & $2002.8-2007.1$ \\
NAHU & -73.031 & -37.824 & 15.6 & 2.78 & 8.6 & 0.24 & -0.74 & 3 & $2003.9-2007.1$ \\
STJU & -72.849 & -37.206 & 28.2 & 2.31 & 7.2 & 1.37 & -0.79 & 2 & $2003.8-2007.0$ \\
STCL & -72.361 & -36.836 & 28.6 & 2.25 & 4.8 & 0.70 & -0.55 & 3 & $2003.8-2007.0$ \\
STDO & -73.546 & -37.023 & 40.1 & 1.90 & 12.1 & 2.61 & -0.69 & 4 & $2004.1-2007.1$ \\
STCA & -73.53 & -37.059 & 38.8 & 1.07 & 10.8 & 1.84 & -0.66 & 4 & $2004.1-2007.1$ \\
TIRU & -73.502 & -38.341 & 19.1 & 2.82 & 12.3 & 1.08 & -0.45 & 4 & $2003.9-2007.1$ \\
TOLT & -73.182 & -39.349 & 17.9 & 1.90 & 7.1 & 2.53 & -0.58 & 3 & $2002.8-2005.9$ \\
VARA & -73.238 & -38.531 & 19.2 & 1.66 & 8.5 & 0.83 & -0.69 & 2 & $2003.8-2005.9$ \\
CONZ & -73.026 & -36.844 & 31.9 & 1.79 & 8.8 & 1.38 & -0.48 & Permanent Site & Since 2002 \\
HUAL & -73.189 & -36.746 & 38.6 & 1.31 & 10.9 & 0.39 & -0.71 & Permanent Site & Since 2005 \\
UDEC & -72.344 & -37.472 & 21.4 & 1.67 & 6.9 & 0.48 & -0.56 & Permanent Site & Since 2006 \\
\hline
\end{tabular}



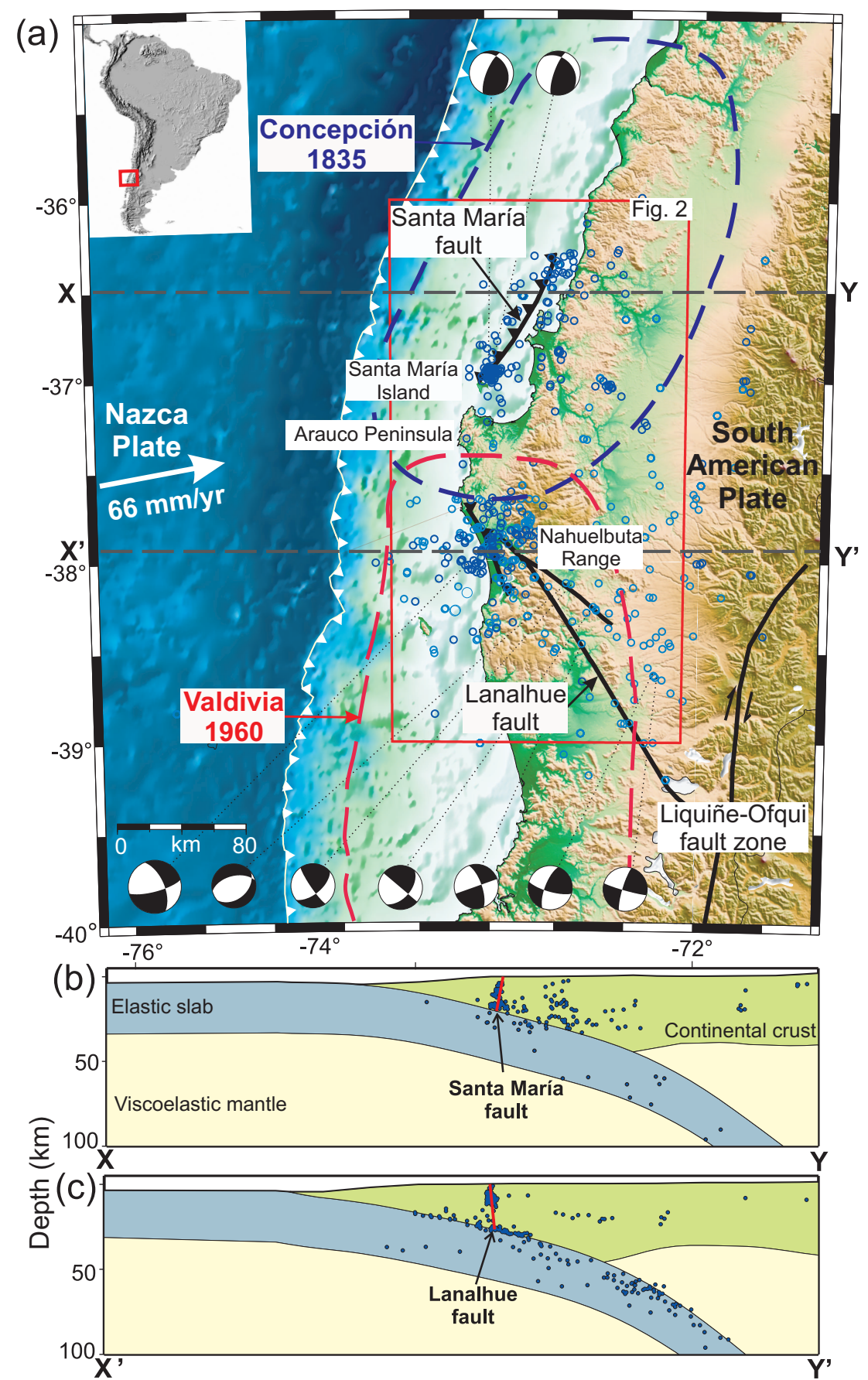

Figure 1. (a) Main tectonic features of the south-central Chile margin. Red box showns the Arauco-Nahuelbuta forearc region. Dotted blue and red lines define the rupture zones of the 1835 and 1960 megathrust earthquakes, respectively [Lomnitz, 2004]. Local seismicity is depicted by open circles [Bohm et al., 2002; Bohm, 2004; Haberland et al., 2006]. Focal mechanisms are from Bruhn [2003] and Haberland et al. [2006]. (b-c) Profiles at $36.5^{\circ}$ and $38^{\circ} \mathrm{S}$ showing cluster of aligned seismicity along the Santa María and Lanalhue faults, respectively. 


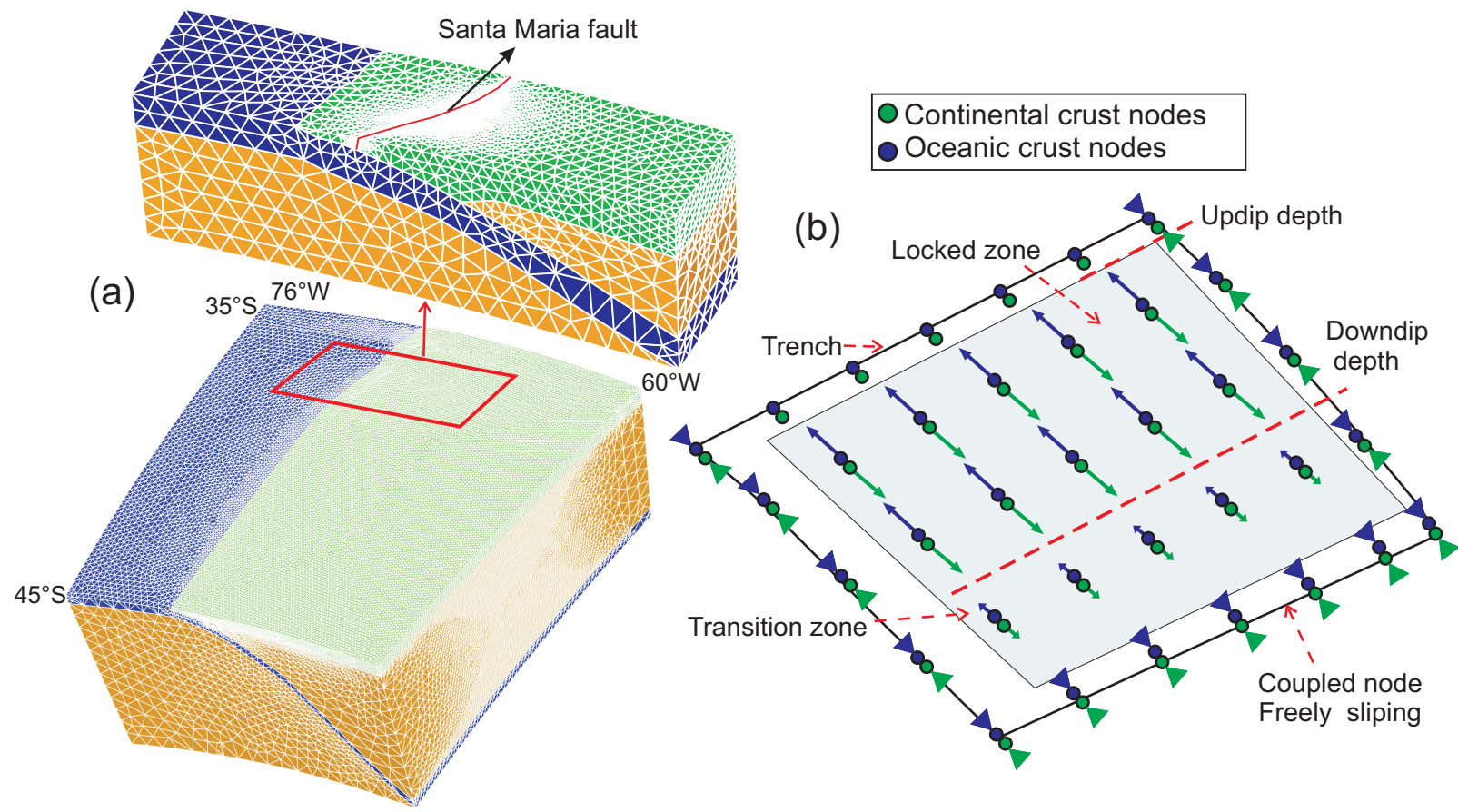

Figure 2. (a) 3-D finite element model setup. Green, blue and orange elements represent the continental and oceanic lithosphere, and mantle, respectively. Extracted portion of the mesh shows detail along the Santa María fault. (b) Schematic representation of nodes in the plate interface. Arrows depict how constraint equations simulate the double-couple acting on the fault. 


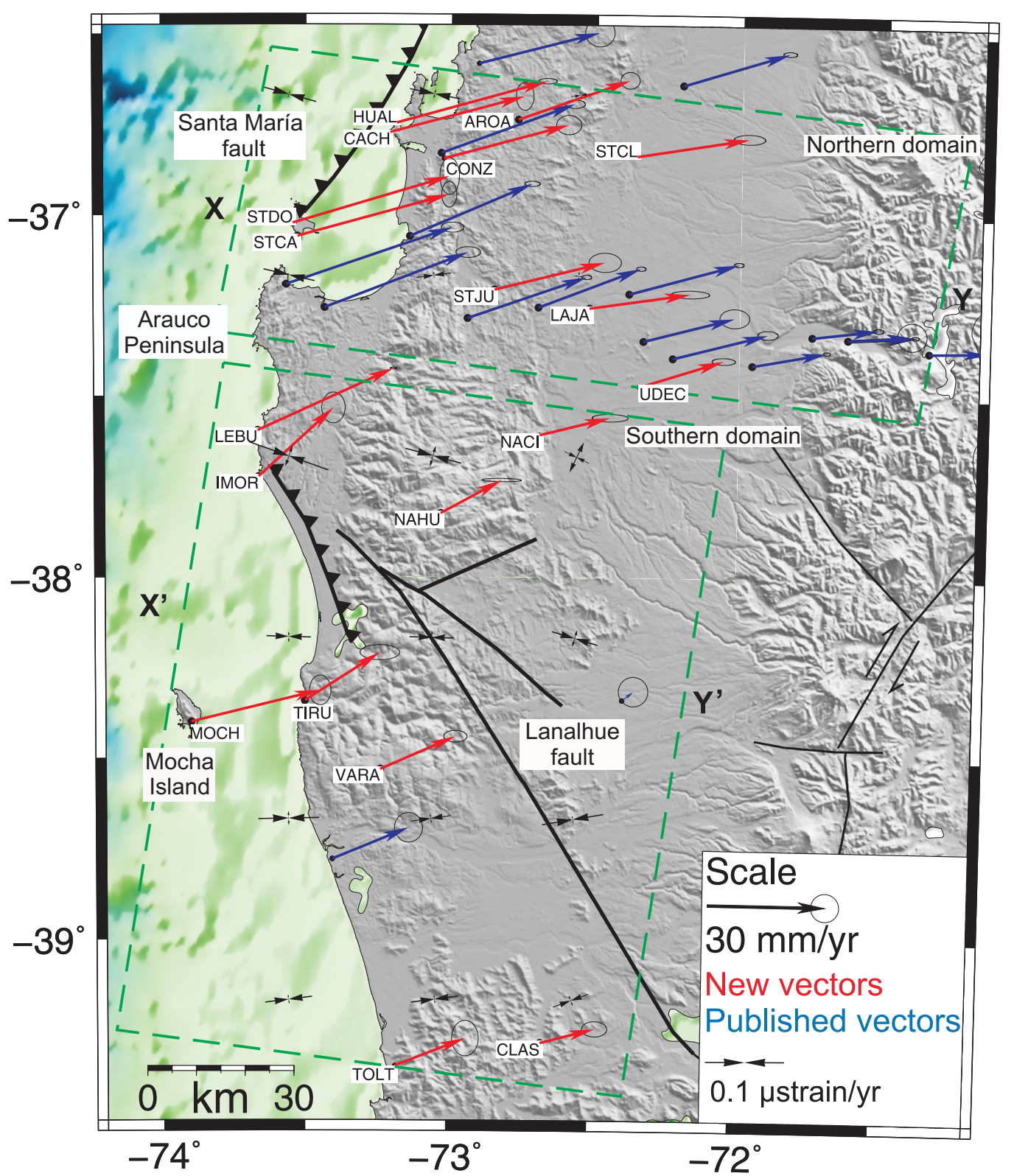

Figure 3. GPS velocity vectors of the south-central Chile forearc relative to a stable South American reference frame. Ellipses represent 95\% confidence limits. New GPS velocities presented in this paper are shown in red (Table 1), velocities by Klotz et al. [2001] and Ruegg et al. [2008] are shown in blue. Principal axes of infinitesimal horizontal strain are depicted by black crosses. The green dotted boxes denote the northern and southern domains, and areas of profiles $\mathrm{XY}$ and $\mathrm{X}^{\prime} \mathrm{Y}^{\prime}$ shown in Figure 4. 


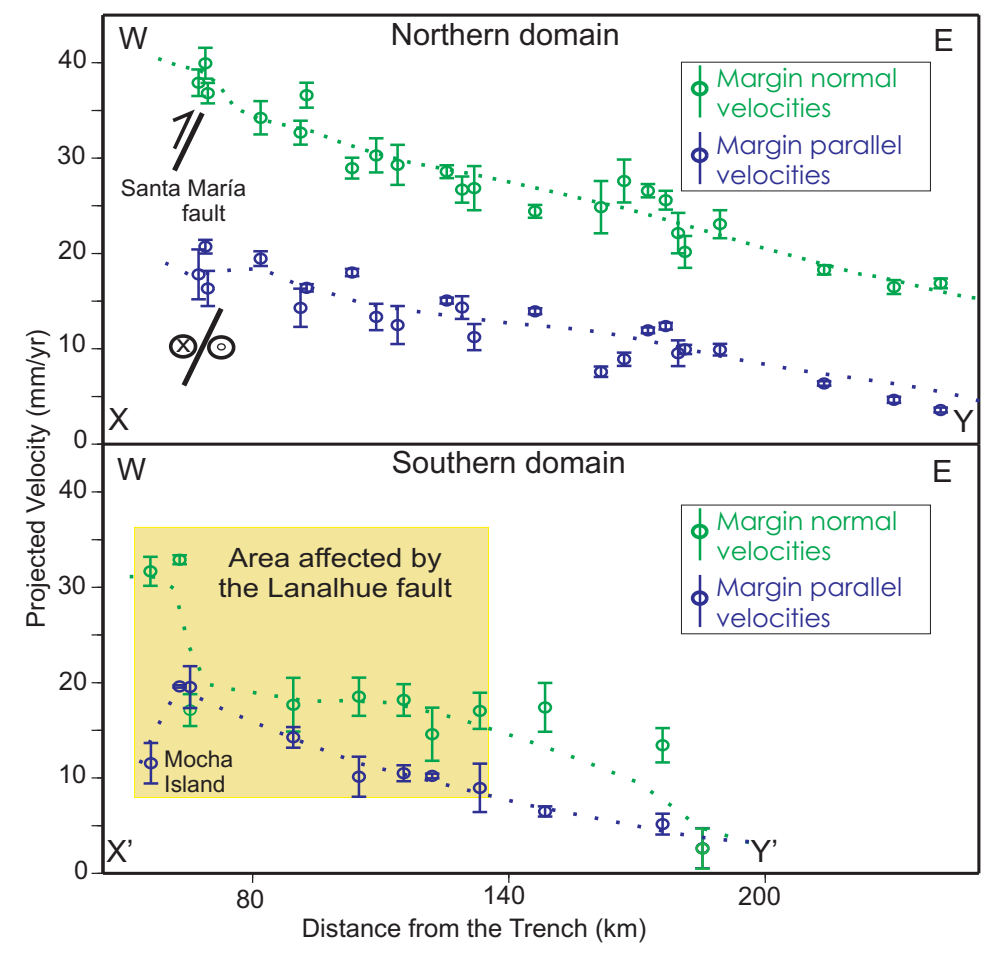

Figure 4. Horizontal GPS velocities from profiles projected normal (blue) and parallel (green) to the margin. Location of profiles in Figure 3. In the northern domain, the Santa María fault is depicted by a solid line. Reverse and dextral-strike slip motion on the fault are indicated. 

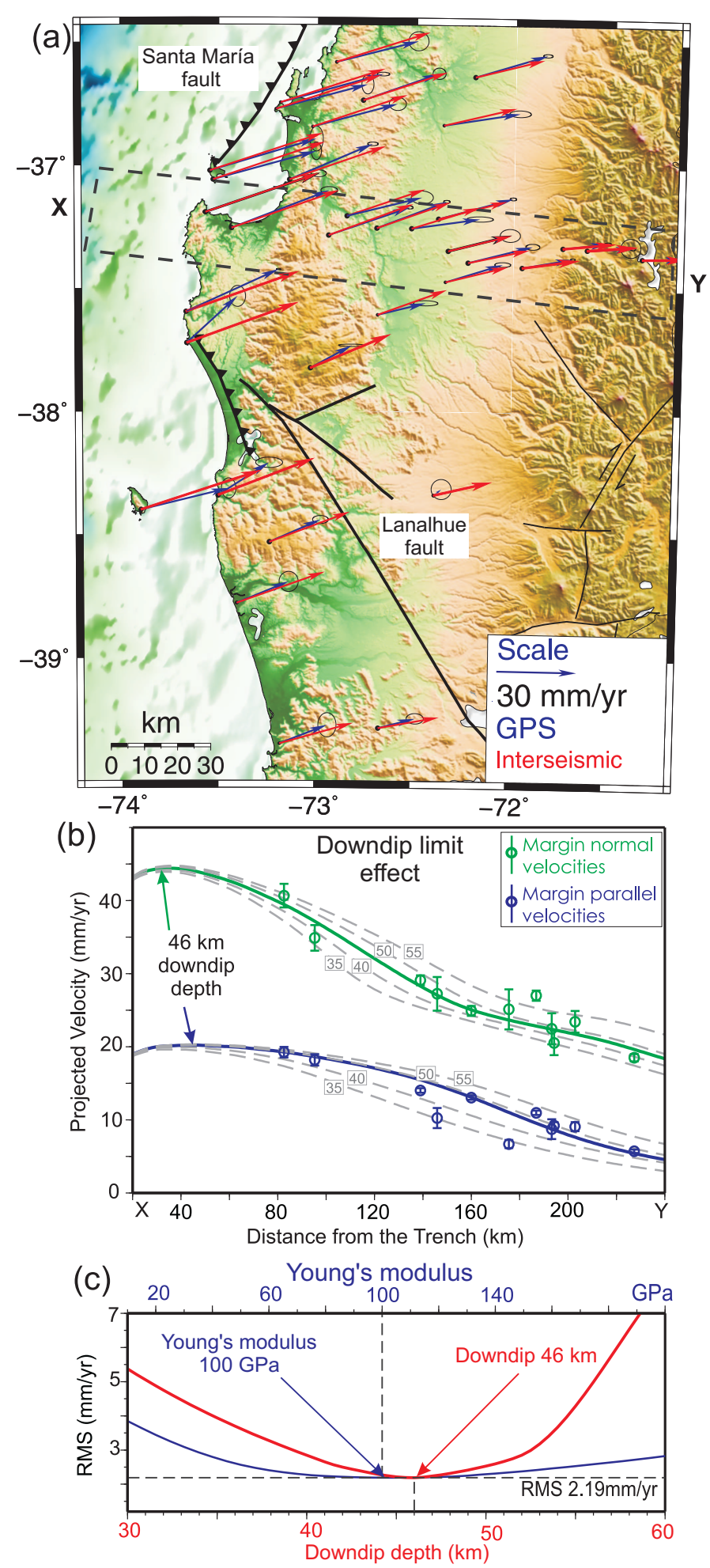

Figure 5. (a) Comparison of the GPS vectors (blue) with the velocities of the interseismic model (red). (b) Margin normal cross section at $37.2^{\circ} \mathrm{S}$. Interseismic model results for different downdip depth limits are plotted. (c) RMS response to downdip depth, and continental Young's modulus variations (See text for detailes).

D R A F T December 8, 2008, 5:17pm 


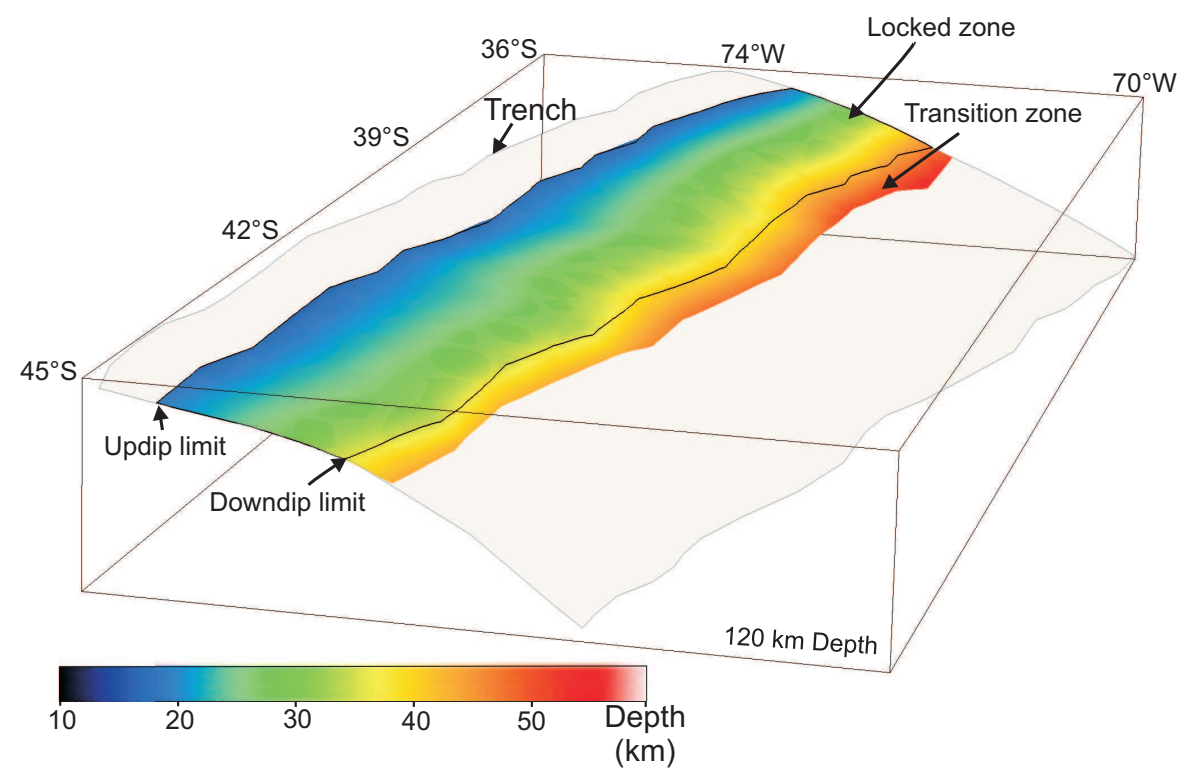

Figure 6. Up- and downdip depth limits of the coupling zone used in our FEM modeling. Below the downdip limit, a 10-km linear transition from fully-coupled to zero slip was applied. The seismogenic zone is wider on the northern part, where it reaches a depth of $49 \mathrm{~km}$. This zone gradually shallows to $35 \mathrm{~km}$ depth at $45^{\circ} \mathrm{S}$

(See text for details). 

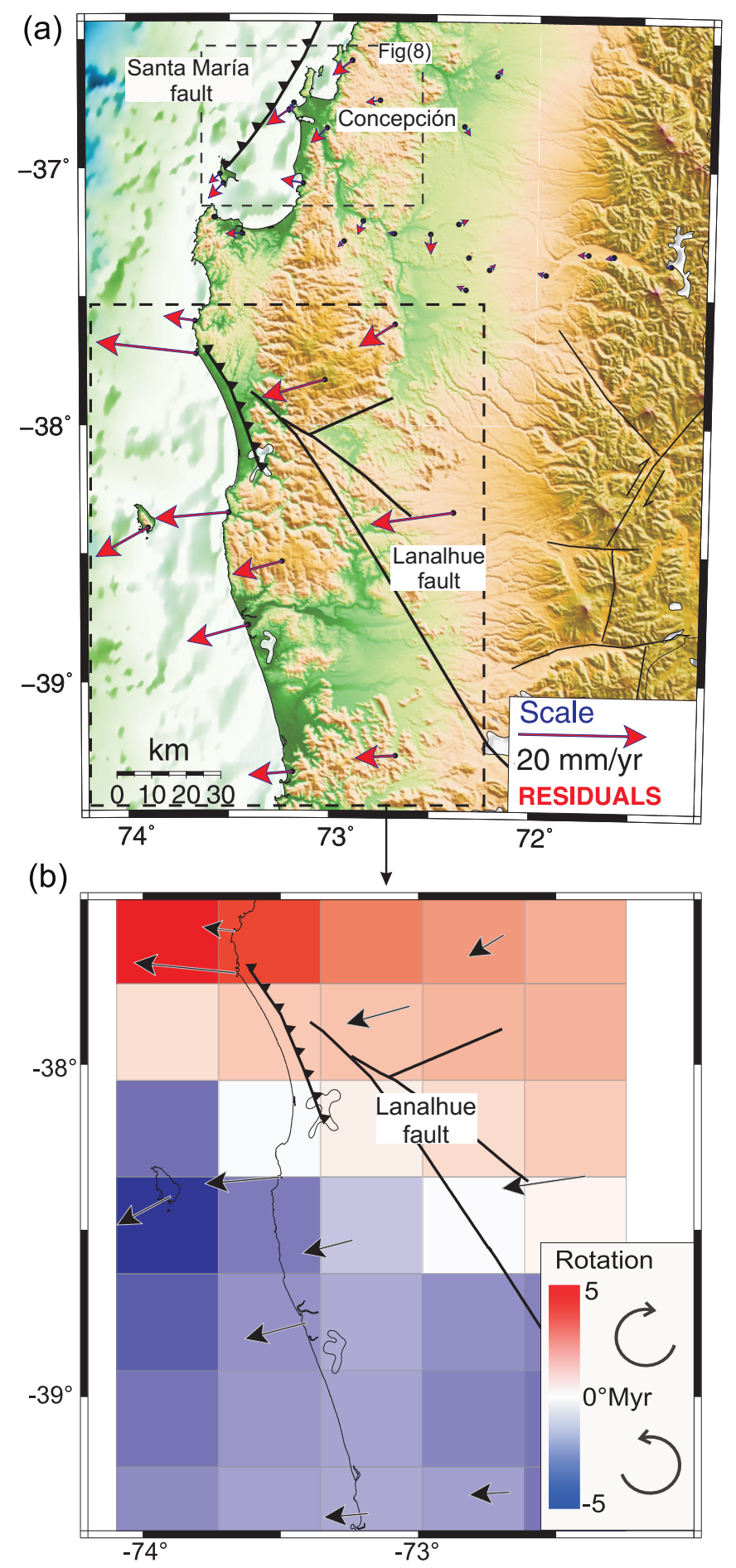

Figure 7. (a) Residual velocities obtained by subtracting the interseismic model from the GPS velocities. (b) Vertical-axis rotation from the interseismic residuals on the southern domain, calculated with the software SSPX [Allmendinger et al., 2007] over a regular grid of $30 \mathrm{~km}$. 

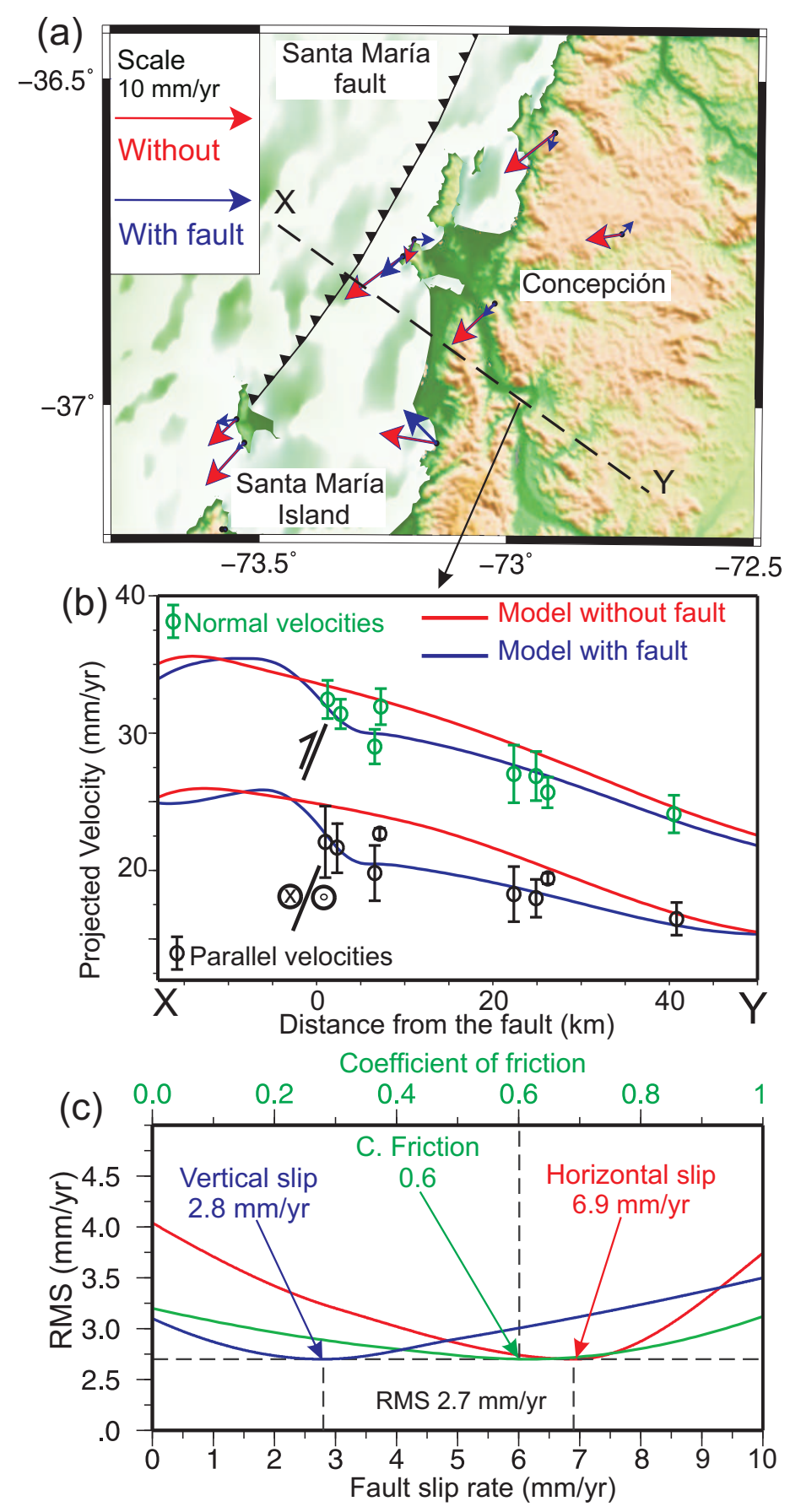

Figure 8. (a) Residuals after subtraction of deformation caused by the interseismic deformation and effect of Santa María fault. (b) Cross section XY normal to the Santa María fault. Interseismic model results with and without effects of the fault are shown. Fault-related deformation extends up to $35 \mathrm{~km}$ from the fault, and may be responsible for the velocity gradient observed in the GPS vectors. (c) RMS response to changes fault slip and friction coefficient. The horizontal fault slip has the principal effect on the RMS. 


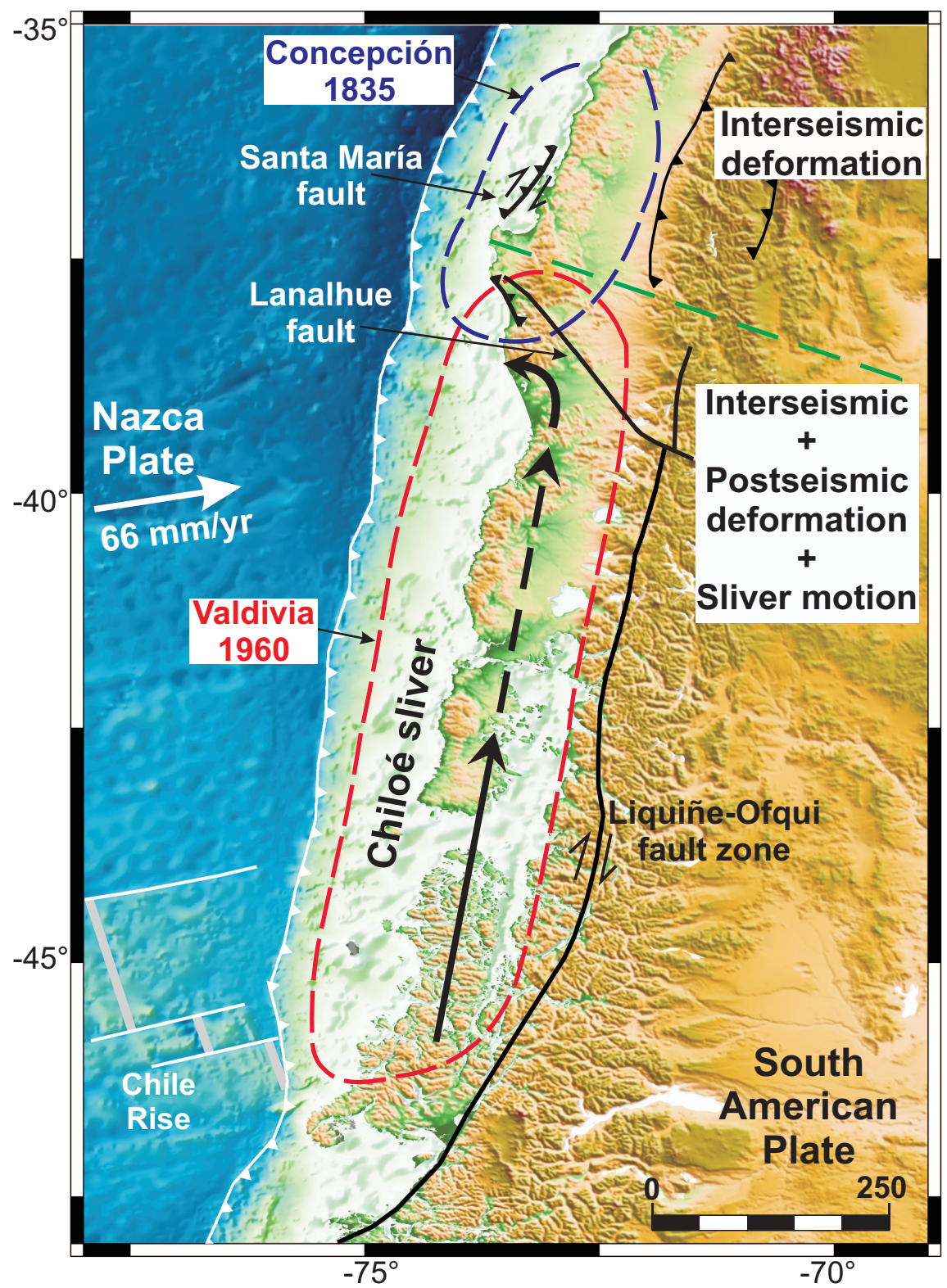

Figure 9. Schematic map showing the main tectonic features that may control the deformation in the south-central Chile margin (See text for details). 